Abstracta Iranica Abstracta Iranica

Revue bibliographique pour le domaine irano-aryen

Volume 24 | 2003

Comptes rendus des publications de 2001

\title{
«A Corpus of Early Fifth Century Seal Impressions in the Yale Babylonian Collection ». Baghdader Mitteilungen 31, (2000), pp. 309-354, 21 pl.
}

\section{Rémy Boucharlat}

\section{(2) OpenEdition}

\section{Journals}

Édition électronique

URL : http://journals.openedition.org/abstractairanica/34290

ISSN : 1961-960X

Éditeur:

CNRS (UMR 7528 Mondes iraniens et indiens), Éditions de l'IFRI

Édition imprimée

Date de publication : 15 mai 2003

ISSN : 0240-8910

Référence électronique

Rémy Boucharlat, « «A Corpus of Early Fifth Century Seal Impressions in the Yale Babylonian Collection ». Baghdader Mitteilungen 31, (2000), pp. 309-354, 21 pl. », Abstracta Iranica [En ligne], Volume 24 | 2003, document 59, mis en ligne le 05 janvier 2010, consulté le 25 septembre 2020. URL : http://journals.openedition.org/abstractairanica/34290

Ce document a été généré automatiquement le 25 septembre 2020.

Tous droits réservés 


\title{
«A Corpus of Early Fifth Century Seal Impressions in the Yale Babylonian Collection ». Baghdader Mitteilungen 31, (2000), pp. 309-354, $21 \mathrm{pl}$.
}

\author{
Rémy Boucharlat
}

Publication d'une série de 82 scellements en terre qui portent une empreinte de cachet ( $70 \%)$ ou de sceau-cylindre ( $27 \%)$. Ils ont été acquis près de Nippur en 1926. Cette collection vient s'ajouter à d'autres provenant de Mésopotamie méridionale, décidément très riche: empreintes des archives des Mura ù à Nippur, des Egibi de Babylone ou des temples, comme l'Eanna d'Uruk ou l'Ebabbar de Sippar. L'iconographie purement achéménide $\mathrm{y}$ est minoritaire, les thèmes les plus fréquents étant mésopotamiens, en pleine époque achéménide; le plus courant est la représentation d'un adorant avec un bras levé, devant un piédestal portant un symbole divin. L'intérêt de ce corpus est de documenter une période mal connue de la domination achéménide, la fin du règne de Darius et celui de Xerxès.

\section{INDEX}

Thèmes : 3.2.2. Pré-Achéménides et Achéménides 
AUTEURS

RÉMY BOUCHARLAT

CNRS - Lyon 